\title{
Occurrence of zoonotic gastrointestinal parasites of rodents and the risk of human infection in different biomes of Brazil
}

\author{
Ocorrência de parasitos gastrointestinais zoonóticos de roedores \\ e o risco de infecção humana em diferentes biomas do Brasil
}

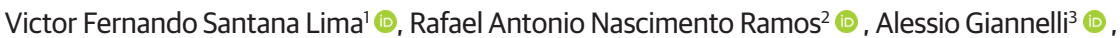

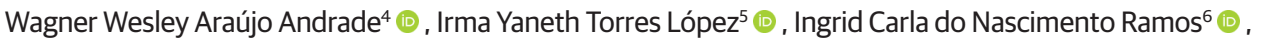

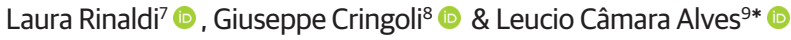 \\ 'Veterinarian, DSc., Unidade de Medicina Veterinária, Universidade Federal de Sergipe (UFS), Nossa Senhora da Glória, SE, Brazil \\ ${ }^{2}$ Veterinarian, DSc., Laboratório de Parasitologia, Universidade Federal do Agreste de Pernambuco (UFAPE), Garanhuns, \\ PE, Brazil \\ ${ }^{3}$ Veterinarian, DSc., Vaxinano, Lille, France \\ ${ }^{4}$ Veterinarian, MSc., Departamento de Medicina Veterinária, Universidade Federal Rural de Pernambuco (UFRPE), Recife, \\ PE, Brazil \\ ${ }^{5}$ Veterinarian, MSc., Universidad de El Salvador, San Salvador, El Salvador \\ ${ }^{6}$ Agronomist, MSc., Laboratorio de Parasitologia, UFRPE, Recife, PE, Brazil \\ 'Veterinarian, DSc., University of Naples Federico II, Napoli, Italy \\ ${ }^{8}$ Veterinarian, DSc., University of Naples Federico II, Napoli, Italy \\ `Veterinarian, DSc., Departamento de Medicina Veterinária, UFRPE, Recife, PE, Brazil
}

\begin{abstract}
Rodents are synanthropic mammals adapted to several ecosystems, where they can contribute to the transmission of zoonotic pathogens, including gastrointestinal parasites. The aim of this study was to study the occurrence of gastrointestinal parasites from rodents and discuss the risk of transmission to humans. Fecal samples $(n=110)$ from different rodent species, namely, Cerradomys subflavus $(n=4)$, Mus musculus $(n=14)$, Rattus norvegicus $(n=80)$, Rattus rattus $(n=8)$ and Thrichomys apereoides $(n=4)$, were analyzed using the FLOTAC technique. Of the samples examined, 73.6\% (81/110) tested positive for at least one gastrointestinal parasite. The most commonly identified parasites were Aspiculuris sp., Hymenolepis nana, Moniliformis sp., Syphacia sp., Strongyloides spp., Taenia spp., and Trichuris spp. eggs, Angiostrongylus cantonensis larvae and Entamoeba spp. cysts. The findings of this study demonstrate that rodents living in different Brazilian biomes are parasitized by a wide range of parasites, including some of public health concern. Therefore, the proximity of rodents to human settlements may represent a tangible risk of infection for people living in these areas.
\end{abstract}

Keywords: zoonosis, parasitological techniques, synanthropic animals, rodent-borne diseases, FLOTAC.

\section{Resumo}

Roedores são mamíferos sinantrópicos adaptados a vários ecossistemas, onde podem contribuir para a transmissão de patógenos zoonóticos, incluindo parasitas gastrointestinais. O objetivo deste estudo foi descrever a ocorrência de parasitos gastrointestinais de roedores e discutir o risco de transmissão ao ser humano. Amostras fecais $(\mathrm{n}=110)$ de diferentes espécies de roedores, a saber, Cerradomys subflavus ( $\mathrm{n}=4)$, Mus musculus $(\mathrm{n}=14)$, Rattus norvegicus $(\mathrm{n}=80)$, Rattus rattus $(\mathrm{n}=8)$ e Thrichomys apereoides $(\mathrm{n}=4)$, foram analisados pela técnica FLOTAC. Das amostras examinadas, 73,6\% (81/110) apresentaram resultado positivo para pelo menos um parasito gastrointestinal. Os parasitos mais comumente identificados foram ovos de Aspiculuris sp., Hymenolepis nana, Moniliformis sp., Syphacia sp., Strongyloides spp., Taenia spp., Trichuris spp., larvas de Angiostrongylus cantonensis e cistos de Entamoeba spp. Os resultados deste estudo demonstraram que os roedores que vivem em diferentes biomas brasileiros são parasitados por uma ampla variedade de parasitos, incluindo alguns problemas de saúde pública. Portanto, a proximidade de roedores com assentamentos humanos pode representar um risco de infecção nessas áreas.

Palavras-chave: zoonose, técnicas parasitológicas, animais sinantrópicos, doenças transmitidas por roedores, FLOTAC.

\section{BJ $\mathrm{M}$ \\ Brazilian Journal of Veterinary Medicine}

p-ISSN 0100-2430

e-ISSN 2527-2179

○
How to cite: Lima, V.F. S., Ramos, R. A. N., Giannelli, A., Andrade, W. W. A., López, I. Y. T., Ramos, I. C. N., Rinaldi, L., Cringoli, G., \& Alves, L. C. (2021). Occurrence of zoonotic gastrointestinal parasites of rodents and the risk of human infection in different biomes of Brazil. Brazilian Journal of Veterinary Medicine, 43, el13820. http://dx.doi. org/10.29374/2527-2179.bjvm113820

\section{Received July 14, 2020.}

Accepted October 17, 2020

\section{*Correspondence}

Leucio Câmara Alves

Departamento de Medicina Veterinária,

Universidade Federal Rural de Pernambuco - UFRPE

Rua Dom Manuel de Medeiros, s/n, Dois Irmãos

CEP 52171-900 - Recife (PE), Brasil

E-mail: leucioalves@gmail.com
Copyright Lima et al. This is an Open Access article distributed under the terms of the Creative Commons Attribution Non-Commercial License which permits unrestricted non-commercial use, distribution, and reproduction in any medium provided the original work is properly cited. 


\section{Introduction}

The order Rodentia includes about 40\% of currently known mammalian species. During their evolution, these small animals have been able to adapt to different environments and to spread throughout the world over time (RatZooMan, 2006). In some cases, rodents have acclimatized so well to synanthropic biomes that they have become an integral part of the environment, thus participating in the life cycle of other animal species. Hence, through either symbiosis or mutualism, rodents can contribute to the spread of parasites of veterinary and medical concern (Rosický, 1978). The term "rodent-borne diseases" has been coined to describe a specific category of diseases, for which rodents act as the main reservoirs of life-threatening pathogens and conditions, such as Lassa fever, Leptospirosis, Plague and gastrointestinal parasites (Ogunniyi et al., 2014; Sumangali et al., 2012).

In terms of zoonotic parasites, their epidemiology shows various modes of transmission (Han et al., 2015). In most cases, rodents show no clinical signs of the presence of some parasites (e.g., Angiostrongylus cantonensis, Hymenolepis diminuta, Giardia spp. and Cryptosporidium spp.), which are highly harmful to humans. In this case scenario, rodents play a pivotal role as disseminators of these pathogens (Costa \& Catto, 1994; Garedaghi \& Khaki, 2014; Hamrick et al., 1990; Kulasiri, 1954; Reginatto et al., 2008; Vitta et al., 2011). Landscape fragmentation and urbanization have long been known to favor the parasitism of rodents by zoonotic gastrointestinal parasites (Jittapalapong et al., 2009; Karesh et al., 2012). In fact, many rodent species exhibit synanthropic behavior and often live in close contact with humans. This close interaction has favored the transmission of parasites between these hosts (Hamrick et al., 1990; Paramasvaran et al., 2009; Vitta et al., 2011).

Very few studies have so far been conducted to elucidate the mechanisms for transmission of rodent-borne parasites. This can be attributed mostly to the difficulty in collecting reliable samples, and to the low sensitivity of some diagnostic tools (Alves et al., 2007; Santos et al., 2015). Therefore, the aim of this study was to detect gastrointestinal parasites in wild and synanthropic rodents from different biomes in Brazil. The risk for infection of humans that share the same ecological niches with these rodents is also discussed.

\section{Material and methods}

\section{Study area and ethical aspects}

This study was conducted from March 2016 to September 2017 in nine different municipalities in the state of Pernambuco, northeastern Brazil (Table 1). These municipalities were situated in two distinct biomes: i) Caatinga, and ii) Atlantic Forest. The Caatinga biome, which is characterized by low trees and a dry environment, is home to a wide diversity of animals. Conversely, the Atlantic forest, which is considered Brazil's most threatened biome, is characterized by the presence of tall trees (e.g., Caesalpinia leiostachya, Cordia superba and Eugenia uniflora) and mangroves.

All the procedures carried out in this study were approved by the Ethics Committee on Animal Use (CEUA) of the Federal Rural University of Pernambuco (Protocol no. 127/2015) and by Brazil's Biodiversity Authorization and Information System (SISBIO), under Protocol no. 50588-1.

\section{Sampling and laboratory procedures}

Rodents were captured using Tomahawk Live Traps (30 x 17.5 x $15.5 \mathrm{~cm}$ ) baited with pineapple and peanut butter. The traps $(n=50)$ were placed at $6: 00 \mathrm{pm}$ and removed at 6:00 am, totaling an effort of 50 traps/night, and 250 trap/nights in five days of capture. Fecal samples were collected from wild $(n=8)$ and synanthropic $(n=102)$ rodents of different species [i.e., Cerradomys subflavus ( $\mathrm{n}=4)$, Mus musculus $(\mathrm{n}=14)$, Rattus norvegicus $(\mathrm{n}=80)$, Rattus rattus ( $\mathrm{n}=8$ ) and Thrichomys apereoides $(\mathrm{n}=4)]$ after spontaneous defecation. These samples were stored in plastic vials containing $10 \%$ formalin until laboratory processing. Using identification keys, all the captured rodents were identified, estimated age and taxonomically classified down to genus based on external characteristics (e.g., body size, weight and coat) (Bonvicino et al., 2008). 
Table 1. Localities per landscape type, mesoregion, their coordinates, sizes, climate and the species of rodents captured per locality in Pernambuco, Brazil.

\begin{tabular}{|c|c|c|c|c|c|c|}
\hline Locality & Biome & Mesoregion & $\begin{array}{c}\text { Geographic } \\
\text { location }\end{array}$ & $\begin{array}{c}\text { Size } \\
{\left[\mathrm{km}^{2}\right]}\end{array}$ & Climate & $\begin{array}{c}\text { Species of } \\
\text { rodents captured }\end{array}$ \\
\hline Barreiros & $\begin{array}{l}\text { Atlantic } \\
\text { forest }\end{array}$ & Forest Zone & $\begin{array}{l}08^{\circ} 49^{\prime} 04^{\prime \prime} \mathrm{S} \\
35^{\circ} 11^{\prime} \mathrm{O} 9^{\prime \prime} \mathrm{W}\end{array}$ & 233,4 & Humid tropical & Rattus norvegicus \\
\hline Bodocó & Caatinga & Backwoods & $\begin{array}{l}07046^{\prime} 42^{\prime \prime} \mathrm{S}, \\
39056^{\prime} 28^{\prime \prime} \mathrm{W}\end{array}$ & $1.616,502$ & $\begin{array}{l}\text { Tropical } \\
\text { semi-arid }\end{array}$ & $\begin{array}{l}\text { Rattus rattus } \\
\text { and Thrichomys } \\
\text { apereoides }\end{array}$ \\
\hline Camaragibe & $\begin{array}{l}\text { Atlantic } \\
\text { forest }\end{array}$ & $\begin{array}{l}\text { Metropolitan } \\
\text { region }\end{array}$ & $\begin{array}{l}08001^{\prime} 18^{\prime \prime} \mathrm{S} \\
34058^{\prime} 52^{\prime \prime} \mathrm{W}\end{array}$ & 51,257 & Humid tropical & $\begin{array}{l}\text { Mus musculus, } \\
\text { Rattus norvegicus } \\
\text { and Rattus rattus }\end{array}$ \\
\hline Carnaíba & Caatinga & Backwoods & $\begin{array}{l}07^{\circ} 48^{\prime} 18^{\prime \prime} \mathrm{S} \\
37^{\circ} 47^{\prime} 38^{\prime \prime} \mathrm{W}\end{array}$ & 437 & $\begin{array}{l}\text { Tropical } \\
\text { semi-arid }\end{array}$ & Rattus norvegicus \\
\hline Flores & Caatinga & Backwoods & $\begin{array}{l}07^{\circ} 51^{\prime} 57^{\prime \prime} \mathrm{S}, \\
37^{\circ} 58^{\prime} 30^{\prime \prime} \mathrm{W}\end{array}$ & 1.011 & $\begin{array}{l}\text { Tropical } \\
\text { semi-arid }\end{array}$ & Rattus norvegicus \\
\hline Gravatá & $\begin{array}{c}\text { Caatinga } \\
\text { and Atlantic } \\
\text { forest }\end{array}$ & Agreste & $\begin{array}{l}08012^{\prime} 04^{\prime \prime} \mathrm{S} \\
35^{\circ} 33^{\prime} 53^{\prime \prime} \mathrm{W}\end{array}$ & 506,785 & $\begin{array}{c}\text { Tropical } \\
\text { semi-arid and } \\
\text { humid tropical }\end{array}$ & $\begin{array}{l}\text { Thrichomys } \\
\text { apereoides }\end{array}$ \\
\hline $\begin{array}{l}\text { Ilha de } \\
\text { Itamaracá }\end{array}$ & $\begin{array}{l}\text { Atlantic } \\
\text { forest }\end{array}$ & $\begin{array}{l}\text { Metropolitan } \\
\text { region }\end{array}$ & $\begin{array}{l}07045^{\prime} 00^{\prime \prime} \mathrm{S} \\
34^{\circ} 51^{\prime} 00^{\prime \prime} \mathrm{W}\end{array}$ & 66.684 & Humid tropical & $\begin{array}{l}\text { Cerradomys } \\
\text { subflavus and } \\
\text { Thrichomys } \\
\text { apereoides }\end{array}$ \\
\hline Olinda & $\begin{array}{l}\text { Atlantic } \\
\text { forest }\end{array}$ & $\begin{array}{l}\text { Metropolitan } \\
\text { region }\end{array}$ & $\begin{array}{l}08000^{\prime} 32^{\prime \prime} \mathrm{S} \\
34051^{\prime} 19^{\prime \prime} \mathrm{W}\end{array}$ & 41,681 & Humid tropical & Rattus norvegicus \\
\hline Recife & $\begin{array}{l}\text { Atlantic } \\
\text { forest }\end{array}$ & $\begin{array}{l}\text { Metropolitan } \\
\text { region }\end{array}$ & $\begin{array}{l}\text { O80 03' 14" S, } \\
34052^{\prime} 52^{\prime \prime} \mathrm{W}\end{array}$ & 218,435 & Humid tropical & $\begin{array}{l}\text { Mus musculus, } \\
\text { Rattus norvegicus } \\
\text { and Rattus rattus }\end{array}$ \\
\hline
\end{tabular}

Lastly, the samples were processed individually by the FLOTAC technique, using two flotation solutions (sodium chloride, specific gravity, s.g. = 1.200 and zinc sulfate, s.g. = 1.350) (Cringoli et al., 2010). All the parasite stages observed in this study were identified based on previously described morphological features and taxonomic keys (Bowman et al., 2010; Taylor et al., 2017).

\section{Data analysis}

The data were statistically analyzed to ascertain absolute and relative frequency. The Chi-Square with Yates correction $\left(\mathrm{x}^{2}\right)$ was used to compare positivity between different sexes, ages and origins, using a significance level of 5\%. All the analyses were performed using BioEstat version 5.0 statistical software (Ayres et al., 2007).

\section{Results}

Overall, 73.6\% (81/110) of the samples tested positive for at least one gastrointestinal parasite (e.g., cysts, eggs and/or larvae). Moreover, 9.8\% of the fecal samples (8/81) were collected from young rodents and 90.2\% (73/81) from adults $\left(\mathrm{x}^{2}=19.68 ; \mathrm{p}=0.0000\right) ; 38.2 \%$ (31/81) came from females and 61.8\% (50/81) from males $\left(x^{2}=0.884 ; \mathrm{p}=0.4714\right)$. In addition, 10.7\% (8/81) and 89.3\% (73/81) were collected from animals inhabiting areas of Caatinga and Atlantic Forest $\left(x^{2}=19.68 ; p=0.0000\right)$, respectively (Table 2$)$. Six different genera of endoparasites were observed in wild (57.2\%) and synanthropic (42.8\%) rodents from the Caatinga biome $(\mathrm{p}=0.0000)$.

Among the positive animals, $71.4 \%$ and $28.6 \%\left(x^{2}=18.68 ; p=0.0000\right)$ were rodents that inhabit forest and urban areas, respectively. In addition, a total of nine different genera of gastrointestinal parasites were identified in synanthropic rodents living in the domiciliary and peridomiciliary area of the metropolitan region of Recife (Atlantic Forest biome). 
Table 2. Frequency of zoonotic gastrointestinal parasites in the fecal samples, according to class, genus or species of parasites and rodent species.

\begin{tabular}{|c|c|c|c|c|c|c|c|}
\hline \multirow[b]{2}{*}{ Class } & \multirow[b]{2}{*}{ Genus/Specie } & \multirow[b]{2}{*}{$\begin{array}{l}\text { Cerradomys } \\
\text { subflavus*a }\end{array}$} & \multicolumn{4}{|c|}{ Number of positive samples of rodent specie } & \multirow[b]{2}{*}{$\begin{array}{c}\text { Frequency } \\
\%(n / N)\end{array}$} \\
\hline & & & $\begin{array}{c}\text { Mus } \\
\text { musculus }\end{array}$ & $\begin{array}{c}\text { Rattus } \\
\text { norvegicus }^{b}\end{array}$ & $\begin{array}{l}\text { Rattus } \\
\text { rattus }\end{array}$ & $\begin{array}{l}\text { Thrichomys } \\
\text { apereoides*c }\end{array}$ & \\
\hline Archiacanthocephala & Moniliformis sp. & & & - & $2 / 8$ & & $\begin{array}{c}1.81 \\
(2 / 110)\end{array}$ \\
\hline \multirow{2}{*}{ Cestoda } & $\begin{array}{c}\text { Hymenolepis } \\
\text { nana }\end{array}$ & $1 / 4$ & & $9 / 80$ & & & $\begin{array}{c}9.09 \\
(10 / 110)\end{array}$ \\
\hline & Taenia spp. & & & $4 / 80$ & & & $\begin{array}{c}3.63 \\
(4 / 110)\end{array}$ \\
\hline \multirow{5}{*}{ Nematoda } & $\begin{array}{l}\text { Angiostrongylus } \\
\text { cantonensis }\end{array}$ & & & $14 / 80$ & & & $\begin{array}{c}12.72 \\
(14 / 110)\end{array}$ \\
\hline & Aspiculuris sp. & & & - & $4 / 8$ & & $\begin{array}{c}3.63 \\
(4 / 110)\end{array}$ \\
\hline & $\begin{array}{l}\text { Strongyloides } \\
\text { spp. }\end{array}$ & $1 / 4$ & $3 / 14$ & $34 / 80$ & $1 / 8$ & & $\begin{array}{c}35.45 \\
(39 / 110)\end{array}$ \\
\hline & Syphacia sp. & & & $5 / 80$ & & & $\begin{array}{c}4.54 \\
(5 / 110)\end{array}$ \\
\hline & Trichuris spp. & $2 / 4$ & & $2 / 80$ & & $4 / 4$ & $\begin{array}{c}7.27 \\
(8 / 110)\end{array}$ \\
\hline Protozoa & Entamoeba spp. & & & $2 / 80$ & $4 / 8$ & & $\begin{array}{c}5.45 \\
(6 / 110)\end{array}$ \\
\hline Number of rodent & & 4 & 14 & 80 & 8 & 4 & 110 \\
\hline
\end{tabular}

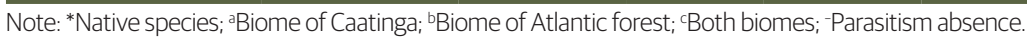

Infection rates with acanthocephalans, cestodes, nematodes and protozoa were 3.1\%, 12.2\%, $75.8 \%$, and 9.1\%, respectively. The parasites most frequently detected were Strongyloides spp. (35.45\%; 39/110) and Hymenolepis nana (9.09\%;10/110; Figure 1a) eggs, Angiostrongylus cantonensis (12.72\%; 14/110) larvae and Entamoeba spp. (5.45\%; 6/110) cysts. As for parasite loads, Strongyloides spp. (up to 10,609 eggs; Figure 1b), H. nana (up to 5,652 eggs), A. cantonensis (up to 3,899 larvae) and Entamoeba spp. (up to 2,124 cysts) were the most abundant.

Coinfections were found in 65.2\% (52/81) of the samples, the most common one being simultaneous infection with $A$. cantonensis larvae and Strongyloides spp. eggs (25\%; 13/52).

The largest number of positive samples (87.8\%; $71 / 81)$ for cysts, eggs and/or larvae of gastrointestinal parasites was found in synanthropic rodents, with eggs of Syphacia sp., Taenia spp. (Figure 1c) and larvae of A. cantonensis detected only in R. norvegicus. Aspiculuris sp. and Moniliformis sp. eggs were identified only in fecal samples from $R$. rattus. Trichuris sp. (Figure 1d) was detected in fecal samples of $R$. norvegicus and T. apereoides.

\section{Discussion}

The findings of this study indicate that synanthropic and wild rodents from Caatinga and Atlantic Forest biomes in Brazil are parasitized by a wide range of gastrointestinal parasite species of public health concern. These findings suggest that landscape features can affect the epidemiology of zoonotic parasites in rodents.

The prevalence data garnered in this study were much higher than those reported in previous surveys conducted in Iran-IRN (Ahmad et al., 2014), Pakistan-PAK (Garedaghi \& Khaki, 2014) and Italy-ITA (d'ovidio et al., 2015), which involved the analysis of rodent fecal samples using the traditional spontaneous sedimentation technique, centrifugal flotation and the FLOTAC method, which reported positivity rates of 13.9\% (500/3,600), 35\% (19/57) and 57\% (24/172), respectively. 


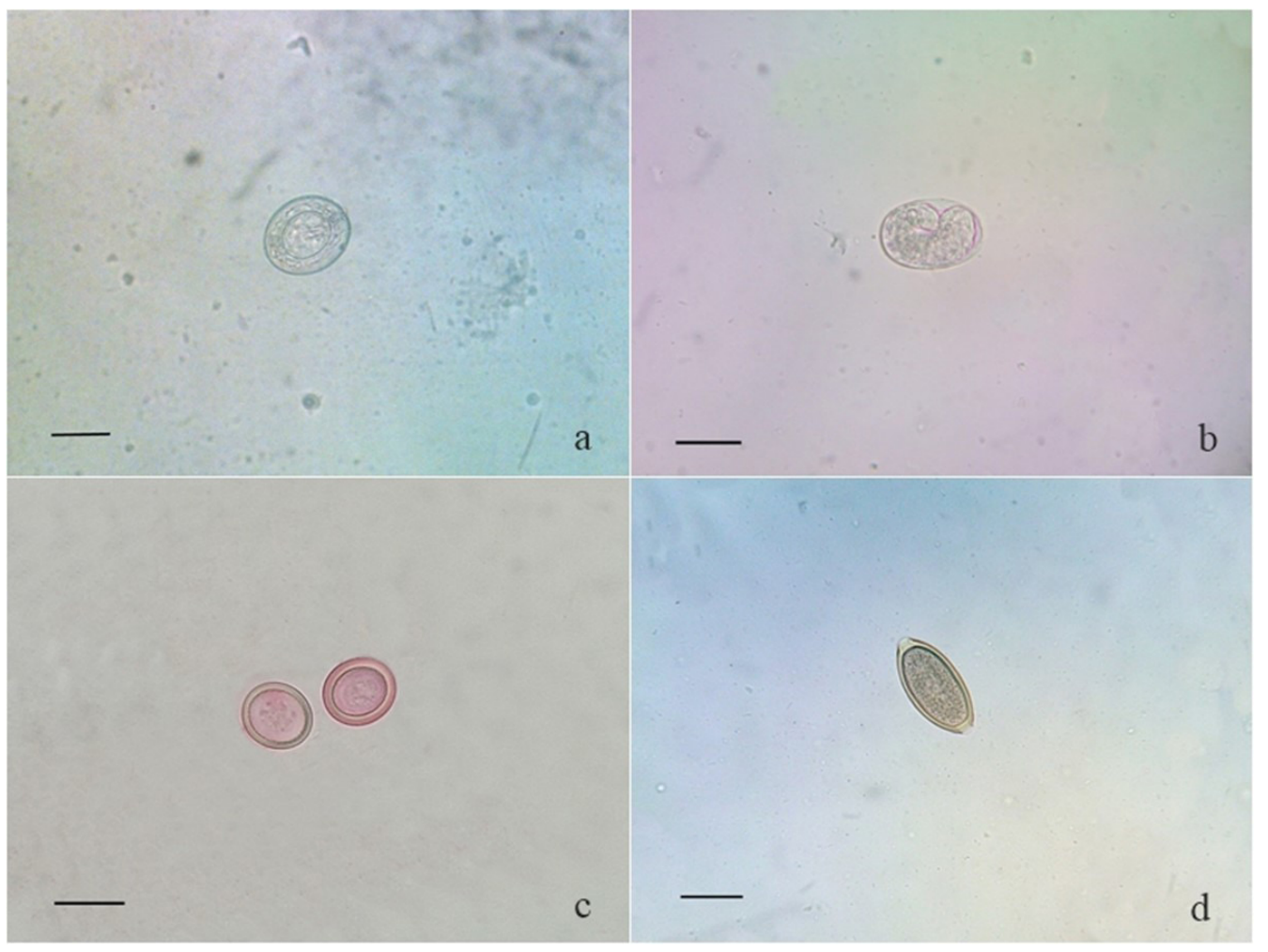

Figure 1. Helminth and cestode eggs detected by FLOTAC in wild and synanthropic rodents in Brazil (Scale bar $=25 \mu \mathrm{m}$ ). (a) Hymenolepis nana: oval egg, 40-60 $\mu \mathrm{m}$ long and 30-50 $\mu \mathrm{m}$ wide, containing oncospheral hooks and polar filaments within the space between the oncosphere and outer shell; (b) Strongyloides spp: thin-shelled oval egg, 40-50 $\mu \mathrm{m}$ long and 30-34 $\mu \mathrm{m}$ wide. (c) Taenia spp.: oval egg, 30-40 $\mu \mathrm{m}$ long and 30-40 $\mu \mathrm{m}$ wide, containing a hexacanth embryo; (d) Trichuris spp.: bar-shaped colorless thick-shelled egg, 48-62 $\mu \mathrm{m}$ long and 29-37 $\mu$ m wide, with bipolar plugs, with 400x objective in optical microscopy.

Among the gastrointestinal pathogens identified in this study, it should be pointed out that the infective stages of parasites of the genera Angiostrongylus, Entamoeba, Hymenolepis, Moniliformis, Strongyloides, Syphacia, Taenia and Trichuris have a proven zoonotic potential (Aghazadeh et al., 2015; Angal et al., 2015; Ashford \& Crewe, 2003; Miyazak, 1991). Hence, the presence of these animals in areas inhabited by humans in Brazil represents a public health risk (Paramasvaran et al., 2009), in view of possible environmental contamination by rodent feces and the parasites they carry.

For Angiostrongylus cantonensis, in particular, causes eosinophilic meningoencephalitis, and this disease has already been identified in Brazil (Caldeira et al., 2007), as do cestodes such as Hymenolepis nana and Taenia spp. (Huggins et al., 1993). In this study, A. cantonensis larvae were detected in fecal samples from $R$. norvegicus, which is considered the definitive natural host. The life cycle of this nematode is generally shared among snails of the species Achatina fulica, Helix aspersa and Helix pomatia as intermediate host, and rodents (Lima et al., 2009; Oliveira et al., 2015; Vitta et al., 2011). Humans are considered accidental hosts infected through the ingestion of third-stage larvae, which, once inside the accidental host, induce acute disease that may even culminate in death or permanent disability (Morassutti et al., 2014). Similarly, H. nana and Taenia spp. are helminths that parasitize humans and may cause diarrhea, abdominal pain, irritability, and weight loss (Galan-Puchades, 2015; Muehlenbachs et al., 2015).

On the other hand, parasites of the genus Syphacia cause asymptomatic infection in their hosts, due to their low pathogenicity or the high degree of host/parasite adaptation. Parasitism of humans by the genus Syphacia is extremely rare, with only a few reports in the United States and Philippines (Pereira, 2009). Moniliformis moniliformis has frequently been detected based on the identification of adult parasites during necropsy examination (Lim et al., 1974). However, in this study, the infection was identified based on the detection of eggs in fecal samples of $R$. rattus. 
Cases of humans infected by this cestode have been described in Japan, where the infection was attributed to the close proximity of infected $R$. norvegicus to dwellings (Miyazak, 1991). With regard to amoebas, the genus Entamoeba is commonly found in rodents (i.e., $R$. norvegicus and $R$. rattus), but a growing number of deaths among human patients have been reported due to this protozoan genus (Lau et al., 2014; Nateghpour et al., 2014; Silva et al., 2014).

In this study, wild rodents from the Caatinga biome were found to carry a smaller variety of gastrointestinal parasites than those from the Atlantic Forest. This finding may be attributed to the high density of human dwellings and factories, which also represent highly populated urban centers (e.g., Camaragibe, Itamaracá, Recife and Olinda). These environments provide optimal conditions for the emergence of several species of synanthropic animals, such as rodents or arthropods (Vasconcelos et al., 2012).

It is important to note that helminth infections may be attributed to the susceptibility of some synanthropic animals, their behavior and immunological status, and environmental contamination (Anderson \& Gordon, 1982; Scott \& Gibbs, 1986). In this context, it has been proven that rodents living in urban areas are potential reservoirs of various species of gastrointestinal parasites (Sumangali et al., 2012). Most likely, urbanization plays an important role in the dissemination of these pathogens, given the close interaction among rodents, domestic animals and humans. The higher frequency of parasites in male (61.8\%) than in female (38.2\%) rodents indicates that the parasite load in these animals probably depends upon sex, and that males usually roam over a wider area in search of food (Ahmad et al., 2014; Ozanan, 1969). Moreover, parasitism is more common in adult rodents than in young animals, probably due to their roaming behavior and the pre-patent period (Stojcevic et al., 2004).

A noteworthy fact is that this is the first time Aspiculuris sp., Moniliformis sp., Taenia spp., and Trichuris spp. eggs, A. cantonensis larvae, and Entamoeba spp. cysts were detected in fecal samples from C. subflavus, M. musculus, R. norvegicus, R. rattus and T. apereoides in Brazil using the FLOTAC technique.

\section{Conclusion}

The findings of this study indicate that a large diversity of zoonotic helminths and protozoa of public health importance can be detected in rodents from Brazil's Caatinga and Atlantic Forest biomes.

\section{Acknowledgements}

The authors are indebted to Professor Gilcia Carvalho, of the Federal Rural University of Pernambuco - UFRPE, for her statistical support.

\section{Ethics statement}

This study was approved by the Ethics Committee on Animal Use (CEUA) of the Federal Rural University of Pernambuco (Protocol no. 127/2015) and by Brazil's Biodiversity Authorization and Information System (SISBIO), under Protocol no. 50588-1) and performed according to the recommendations of the Brazilian College of Animal Experimentation.

\section{Financial support}

None.

\section{Conflict of interests}

VFSL, RANR, AG, WWAA, IYTL, ICNR, LR, GC and LCA - No conflict of interest.

\section{Authors' contributions}

VFSL, RANR and LCA - Development of methodology; preparation and writing the initial draft, Application of statistical study data, AG, WWAA,IYTL,ICHR,LR,GC - Review and Editing manuscript 


\section{Availability of complementary results}

None

The study was carried out at Departamento de Medicina Veterinária, Universidade Federal Rural de Pernambuco (UFRPE), Recife, PE, Brasil.

\section{References}

Aghazadeh, M., Reid, S. A., Aland, K. V., Restrepo, A. C., Traub, R. J., Mccarthy, J. S., \& Jones, M. K. (2015). A survey of Angiostrongylus species in definitive hosts in Queensland. International Journal for Parasitology. Parasites and Wildlife, 4(3), 323-328. http://dx.doi.org/10.1016/i.ijppaw.2015.06.003. PMid:26236633.

Ahmad, M. S., Maqbool, A., Anjum, A. A., Ahmad, N., Khan, M. R., Sultana, R., \& Ali, M. A. (2014). Occurance of Hymenolepis diminuta in rats and mice captured from urban localities of Lahore, Pakistan. The Journal of Animal and Plant Sciences, 24(2), 392-396. http://dx.doi.org/10.1186/s12879-015-1178-3.

Alves, L. C., Borges, C. C. A., Silva, S., Couto, S. E. R., \& Menezes, R. C. (2007). Endoparasitos em cobaias (Cavia porcellus) (Mammalia, Rodentia, Caviidae) provenientes de biotérios de criação e experimentação do município do Rio de Janeiro, Brasil. Ciência Rural, 37(5), 1380-1386. http://dx.doi.org/10.1590/ s0103-84782007000500025.

Anderson, R. M., \& Gordon, D. M. (1982). Processes influencing the distribution of parasite numbers within host populations on with special emphasis on parasite-induced host mortalities. Parasitology, 85(Pt 2), 373-398. http://dx.doi.org/10.1017/S0031182000055347. PMid:7145478.

Angal, L., Mahmud, R., Samin, S., Yap, N. J., Ngui, R., Amir, A., Ithoi, I., Kamarulzaman, A., \& Lim, Y. A. (2015). Determining intestinal parasitic infections (IPIs) in inmates from Kajang Prison, Selangor, Malaysia for improved prison management. BMC Infectious Diseases, 15(1), 467. http://dx.doi.org/10.1186/s12879-0151178-3. PMid:26511347.

Ashford, R. W., \& Crewe, W. (2003). The parasites of Homo sapiens - an annotated checklist of the protozoa, helminths and arthropods for which we are home. Parasite Immunology, 25(7), 401. http://dx.doi. org/10.1046/j.1365-3024.2003.00644.x.

Ayres, M., Ayres Júnior, M., Ayres, D. L., Santos, A. S., \& Ayres, L. L. (2007). BIOESTAT - aplicações estatísticas nas áreas das Ciências Bio-Médicas (381 p.). Belém: Sociedade Civil Mamirauá.

Bonvicino, C. R., Oliveira, J. A., \& D'andrea, P. S. (2008). Guide Rodent Brazil, with keys to genres based on external characters (122 p.). Rio de Janeiro: Centro Pan-Americano de Febre Aftosa - OPAS/OMS.

Bowman, D. D., Lynn, R. C., Eberhard, M. L., \& Alcaraz, A. (2010). Parasitologia veterinária de Georgis (422 p.). São Paulo: Elsevier.

Caldeira, R. L., Mendonça, C. L. G. F., Goveia, C. O., Lenzi, H. L., Graeff-Teixeira, C., Lima, W. S., Mota, E. M., Pecora, I. L., Medeiros, A. M. Z., \& Carvalho, O. S. (2007). First record of mollusks naturally infected with Angiostrongylus cantonensis (Chen, 1935) (Nematoda: Metastrongyloidea) in Brazil. Memorias do Instituto Oswaldo Cruz, 102(7), 887-889. http://dx.doi.org/10.1590/S0074-02762007000700018. PMid:18094889.

Costa, C. A. F., \& Catto, J. B. (1994). Helminth parasites of capybara (Hydrochoerus hydrochaeris) in the subregion Nhecolândia, Pantanal South Mato Grosso. Revista Brasileira de Biologia, 54(1), 39-48. PMid:8209035.

Cringoli, G., Rinaldi, L., Maurelli, M. P., \& Utzinger, J. (2010). FLOTAC: new multivalent techniques for qualitative and quantitative copromicroscopic diagnosis of parasites in animals and humans. Nature Protocols, 5(3), 503-515. http://dx.doi.org/10.1038/nprot.2009.235. PMid:20203667.

d'ovidio, D., Noviello, E., Pepe, P., Del Prete, L., Cringoli, G., \& Rinaldi, L. (2015). Survey of Hymenolepis spp. in pet rodents in Italy. Parasitology Research, 114(12), 4381-4384. http://dx.doi.org/10.1007/s00436-015-4675-9. PMid:26290218.

Galan-Puchades, M. T. (2015). Hymenolepis nana vs. Taenia solium life cycle. Parasite Immunology, 37(8), 429. http://dx.doi.org/10.1111/pim.12204. PMid:26216023.

Garedaghi, Y., \& Khaki, A. A. (2014). Prevalence of Gastrointestinal and Blood Parasites of Rodents in Tabriz, Iran, with Emphasis on Parasitic Zoonoses. Crescent Journal of Medical and Biological Sciences, 1(1), 9-12.

Hamrick, H. J., Bowdre, J. H., \& Church, S. M. (1990). Rat tapeworm (Hymenolepis diminuta) infection in a child. The Pediatric Infectious Disease Journal, 9(3), 216-219. http://dx.doi.org/10.1097/00006454-199003000-00016. PMid:2186353.

Han, B. A., Schmidt, J. P., Bowden, S. E., \& Drake, J. M. (2015). Rodent reservoirs of future zoonotic diseases. Proceedings of the National Academy of Sciences of the United States of America, 112(22), 7039-7044. http://dx.doi.org/10.1073/pnas.1501598112. PMID: 26038558.

Huggins, D. W., Medeiros, L. B., \& Oliveira, E. R. (1993). Hymenolepiasis update and prevention at the Hospital das Clinicas, UFPE. Revista de Patologia Tropical. https://docplayer.com.br/44079669-Himenolepiase-atualizacaoe-prevalencia-no-hospital-das-clinicas-da-ufpe.html 
Jittapalapong, S., Herbreteau, V., Hugot, J. P., Aresrisom, P., Karnchananabanthoeng, A., Rerkamnuaychoke, W., \& Morand, S. (2009). Relationship of parasites and pathogens diversity to rodents in Thailand. Witthayasan Kasetsat Witthayasat, 43, 106-117.

Karesh, W. B., Dobson, A., Lloyd-Smith, J. O., Lubroth, J., Dixon, M. A., Bennett, M., Aldrich, S., Harrington, T., Formenty, P., Loh, E. H., Machalaba, C. C., Thomas, M. J., \& Heymann, D. L. (2012). Ecology of zoonoses: natural and unnatural histories. Lancet, 380(9857), 1936-1945. http://dx.doi.org/10.1016/S0140-6736(12)61678-X. PMid:23200502.

Kulasiri, C. (1954). Some cestodes of the rat, Rattus rattus Linnaeus, of Ceylon and their epidemiological significance for man. Parasitology, 44(3-4), 349-352. http://dx.doi.org/10.1017/S0031182000019004. PMid:13214908.

Lau, Y. L., Jamaiah, I., Rohela, M., Fong, M. Y., Siti, C. O., \& Siti, F. A. (2014). Molecular detection of Entamoeba histolytica and Entamoeba dispar infection among wild rats in Kuala Lumpur, Malaysia. Tropical Biomedicine, 31(4), 721-727. PMid:25776597.

Lim, B. L., Ramachandran, C. P., \& Krishnasamy, M. (1974). Helminth infection among small mammals in Penang Island, Peninsula Malaysia. Federation Museum Journal, 19, 57-65.

Lima, A., Mesquita, S., Santos, S., Aquino, E., Rosa, L., Duarte, F., Teixeira, A., Costa, Z., \& Ferreira, M. (2009). Alicata disease: neuroinfestation by Angiostrongylus cantonensis in Recife, Pernambuco, Brazil. Arquivos de Neuro-Psiquiatria, 67(4),1093-1096. http://dx.doi.org/10.1590/S0004-282X2009000600025. PMid:20069226.

Miyazak, I. (1991). An illustrated book of helminth zoonoses. Tokyo: SEAMIC Publication.

Morassutti, A. L., Thiengo, S. C., Fernandez, M., Sawanyawisuth, K., \& Graeff-Teixeira, C. (2014). Eosinophilic meningitis caused by Angiostrongylus cantonensis: an emergent disease in Brazil. Memorias do Instituto Oswaldo Cruz, 109(4), 399-407. http://dx.doi.org/10.1590/0074-0276140023. PMid:25075779.

Muehlenbachs, A., Bhatnagar, J., Agudelo, C. A., Hidron, A., Eberhard, M. L., Mathison, B. A., Frace, M. A., Ito, A., Metcalfe, M. G., Rollin, D. C., Visvesvara, G. S., Pham, C. D., Jones, T. L., Greer, P. W., Vélez Hoyos, A., Olson, P. D., Diazgranados, L. R., \& Zaki, S. R. (2015). Malignant Transformation of Hymenolepis nana in a Human Host. The New England Journal of Medicine, 373(19), 1845-1852. http://dx.doi.org/10.1056/NEJMoa1505892. PMid:26535513.

Nateghpour, M., Motevalli-Haghi, A., Akbarzadeh, K., Akhavan, A. A., Mohebali, M., Mobedi, I., \& Farivar, L. (2014). Endoparasites of Wild Rodents in Southeastern Iran. Journal of Arthropod-Borne Diseases, 9(1), 1-6. PMid:26114139.

Ogunniyi, T., Balogun, H., \& Shasanya, B. (2014). Ectoparasites and endoparasites of peridomestic house-rats in ile-ife, Nigeria and implication on human health. Iranian Journal of Parasitology, 9(1), 134-140. PMid:25642271.

Oliveira, A. P., Gentile, R., Maldonado Júnior, A., Lopes Torres, E. J., \& Thiengo, S. C. (2015). Angiostrongylus cantonensis infection in mollusks in the municipality of São Gonçalo, a metropolitan area of Rio de Janeiro, Brazil: role of the invasive species Achatina fulica in parasite transmission dynamics. Memorias do Instituto Oswaldo Cruz, 110(6), 739-744. http://dx.doi.org/10.1590/0074-02760150106. PMid:26517652.

Ozanan, C. C. A. F. (1969). Notas sobre o rato de cana, "Holochilus sciures", na região do Cariri, Ceará. Revista Brasileira de Biologia, 29(4), 5667-5670.

Paramasvaran, S., Sani, R. A., Hassan, L., Hanjeet, K., Krishnasamy, M., John, J., Santhana, R., Sumarni, M. G., \& Lim, K. H. (2009). Endo-parasite fauna of rodents caught in five wet markets in Kuala Lumpur and its potential zoonotic implications. Tropical Biomedicine, 26(1), 67-72. PMid:19696729.

Pereira, V. M. M. (2009). Study of helminth fauna of Mus musculus (Rodentia) in São Miguel (Açores): inducing factors of diversity and zoonotic potential [Unpublished master's degree] University of Lisbon.

RatZooMan. (2006 May). Rats and human health in Africa: Proceedings of an International Workshop on Rodent Borne Diseases and the Rat Zoo Man Research Project. In RatZooMan Workshop. United Kingdom: Natural Resources Institute. http://projects.nri.org/ratzooman/docs/workshop_proceedings.pdf

Reginatto, A. R., Farret, M. H., Fanfa, V. R., Silva, A. S., \& Monteiro, S. G. (2008). Infection by Giardia spp. and Cystoisospora spp. in capybara and agouti in southern Brazil. Revista Portuguesa de Ciências Veterinárias, 107(565-566), 96-99.

Rosický, B. (1978). Animals, parasites and zoonoses in different types of urban areas. Folia Parasitologica https://www.ncbi.nlm.nih.gov/pubmed/568098

Santos, F. G. A., Zamora, L. M., Fonseca, F. C. E., \& Ribeiro, V. M. (2015). Intestinal parasites control of capybaras (Hydrochoerus hydrochaeris) raised in semi-extensive system, at Senator Guimard Santos district, Acre, Brazil. Acta Veterinaria Brasilica, 5(1), 393-398.

Scott, M. E., \& Gibbs, H. C. (1986). Long-term population dynamics of pinworms (Syphacia obvelata and Aspiculuris tetraptera) in mice. The Journal of Parasitology, 72(5), 652-662. http://dx.doi.org/10.2307/3281452. PMid:3806316.

Silva, M. T. N., Santana, J. V., Bragagnoli, G., Marinho, A. M. N., \& Malagueño, E. (2014). Prevalence of Entamoeba histolytica/Entamoeba dispar in the city of Campina Grande, in Northeastern Brazil. Revista do Instituto de Medicina Tropical de São Paulo, 56(5), 451-454. http://dx.doi.org/10.1590/S0036-46652014000500015. PMid:25229229.

Stojcevic, D., Mihljevic, Z., \& Marnculic, A. (2004). Parasitological survey of rats in rural regions of Croatia. Veterinární Medicína Czech, 49(3), 70-74. 
Sumangali, K., Rajapakse, R. P. V. J., \& Rajakaruna, R. S. (2012). Urban rodents as potential reservoirs of zoonoses: a parasitic survey in two selected areas in Kandy district. The Ceylon Journal of Science, 41(1), 71-77. http://dx.doi.org/10.4038/cjsbs.v4111.4539.

Taylor, M. A., Coop, R. L., \& Wall, R. L. (2017). Parasitologia veterinária (3. ed). Rio de Janeiro: Guanabara Koogan.

Vasconcelos, C. H., Fonseca, F. R., Lise, M. L. Z., \& Arsky, M. L. N. (2012). Environmental and socioeconomic factors related to the distribution of leptospirosis cases in the state of Pernambuco, Brazil, 2001-2009. Cadernos Saúde Coletiva, 20(11), 49-56.

Vitta, A., Polseela, R., Nateeworanart, S., \& Tattiyapong, M. (2011). Survey of Angiostrongylus cantonensis in rats and giant African land snails in Phitsanulok province, Thailand. Asian Pacific Journal of Tropical Medicine, 4(8), 597-599. http://dx.doi.org/10.1016/S1995-7645(11)60154-5. PMid:21914534. 